\title{
PENGARUH PENAMBAHAN BOKHASI KUBIS (Brassica oleracea var. capitata) TERHADAP PERTUMBUHAN BAWANG PUTIH (Allium sativum L) PADA TANAH PODZOLIK MERAH KUNING
}

\author{
Wike Samira Frona, Anizam Zein, Vauzia \\ Jurusan Biologi FMIPA UniversitasNegeri Padang. \\ Jalan Prof. Dr. Hamka Air Tawar Barat Padang \\ Email: wikesamirafrona@gmail.com
}

\begin{abstract}
Garlic (Allium sativum. L) constitute one of plant which requisition high it at marketing because has a lot of benefit as condiment of cookery, as salving as and effects anti microbe. For meeting that marketing requisition needs improved its production. One of problem in garlic instilling is media plant out that has to increase low fecundity as soiled as podzolik tingles to yellow (PMK). Therefor needs effort for added organic fertiliser, one of that potentially is cabbage waste (Brassicaoleracea var. capitata) one that made by bokhasi with EM4'S application (Effective Microorganisms 4). Base that thing was done research about bokhasi's increase influence cabbage (Brassicaoleraceavar. capitata) to garlic growth (Allium sativum. L) on podzolik's earth tingles to yellow. Research is done on January until May 2015, at Bagiriak's Stone, Elongated allergy and Botanical Physiology Laboratory, FMIPA UNP. This experiment research utilize random design furnished with 5 conducts and 4 dry runs. Conduct that is given is distinctive dosed bokhasi's manure cabbage which is conduct $\mathrm{A}=0 \mathrm{~g} /$ polibagbokhasi cabbages, conduct $\mathrm{b}=250 \mathrm{~g} /$ polibag, conduct $\mathrm{c}=500 \mathrm{~g} /$ polibag, conduct $\mathrm{d}$. $=750 \mathrm{~g} /$ polibag, and conduct $\mathrm{e}=1000 \mathrm{~g} /$ polibag. Observed parameter is tall plant, total helai leaf, total fang / corm, wet weight, dry weight, total root and $\mathrm{pH}$ is earth. dianalisis's data by use of ANOVA and lanjut DNMRT's quiz on level 5\%. Result observationaling to point out that bokhasi's application cabbage significanting to high, total helai leaf, total fang / corm, wet weight, dry weight, and plant root amount garlic and not give reality influence on $\mathrm{pH}$ earth.
\end{abstract}

Key words: bokhasi, cabbage, garlic, podzolik's earth tingles to yellow

\section{PENDAHULUAN}

Bawang putih (Allium sativum L) merupakan salah satu tanaman yang tinggi permintaannya di pasaran karena memiliki banyak manfaat sebagai bumbu masakan, obatobatan, dan salah satu sumber pertumbuhan baru ekonomi dalam pembangunan pertanian. Dalam industri makanan, umbi bawang putih dijadikan ekstrak, bubuk atau tepung, dan diolah menjadi acar. Di bidang kesehatan, bawang putih sudah diteliti mengenai efek anti mikroba misalnya antiparasit terhadap Cappilaria sp [1].

Kebutuhan masyarakat terhadap bawang putih per kapita per tahun kecenderungan meningkat. Pada saat ini produksi bawang putih dalam negeri yang rendah belum dapat memenuhi permintaan tersebut. Impor bawang putih Indonesia berjumlah 295 ribu ton dengan nilai tidak kurang dari US\$ 103 juta atau sebesar Rp 927 milyar. Peningkatan kesadaran dalam negeri untuk mengurangi ketergantungan impor bawang putih membuat pengembangan bawang putih di Indonesia digalakkan [2].

Secara umum, bawang putih hanya cocok ditanam di dataran tinggi meskipun sekarang ditemukan beberapa varietas toleran dataran 
rendah [3]. Varietas bawang putih yang berkembang di Indonesia umumnya memiliki potensi hasil yang jauh lebih rendah dibandingkan dengan potensi hasil bawang putih di daerah subtropis. Hal ini disebabkan oleh keterbatasan dalam budidaya tanaman seperti media tanah yang digunakan, pengendalian hama, penyakit tanaman, gulma, pemupukan, dan penanganan pasca panen.

Salah satu jenis tanah yang mendominasi $25 \%$ daratan pada lahan kering di Indonesia yaitu tanah Podzolik Merah Kuning (PMK). Tanah PMK tidak digunakan sebagai lahan pertanian karena tingkat kesuburannya rendah dan pada saat kering akan mengeras. Tanah ini memiliki pH sekitar 3,5 4,0 sehingga bersifat asam [4]. Tanah PMK miskin unsur hara makro $(\mathrm{N}, \mathrm{P}, \mathrm{K}$ dan $\mathrm{S})$ dan hara mikro ( $\mathrm{Zn}$ dan $\mathrm{Mg}$ ), kandungan bahan organik yang rendah dan memiliki kadar aluminium (Al) yang tinggi dapat menyebabkan keracunan bagi tanaman.

Pemberian pupuk organik dapat memperbaiki struktur tanah menjadi lebih gembur, sehingga sistem perakaran dapat berkembang lebih baik dan proses penyerapan unsur hara berjalan lebih optimal [5]. Pupuk organik ramah lingkungan, bernilai ekonomis dan bahannya mudah didapatkan.

Sumber bahan yang dapat dimanfaatkan untuk pupuk organik sangat beranekaragam, diantaranya dari limbah sayuran. Tempat yang banyak terdapat limbah sayuran yaitu di pasar. Pada dasarnya, sifat sayuran mudah rusak dan membusuk. Masyarakat membuang sayuran yang membusuk tersebut, sehingga menambah tumpukan sampah dan menimbulkan bau yang tidak sedap [6].

Salah satu sayuran yang bisa di manfaatkan yaitu kubis. Limbah kubis dapat dijadikan pupuk organik (kompos) untuk membantu pertumbuhan tanaman bawang putih. Kubis merupakan salah satu sayuran yang mengandung gizi lengkap. Unsur Semua keluarga kubis-kubisan mengandung senyawa anti kanker dan merupakan sumber vitamin $\mathrm{C}$, vitamin $\mathrm{A}$, vitamin $\mathrm{B} 1$, mineral, kalsium, kalium, klor, fosfor, sodium dan sulfur[7]. Kubis salah satu hasil dari produksi sayuran di Indonesia dan banyak dikonsumsi oleh masyarakat.

Kubis mengandung salah satu unsur hara esensial yaitu sulfur. Sulfur sangat di perlukan tanaman bawang putih. Tanaman menyerap sulfur dalam bentuk ion sulfat yang tidak banyak terdapat di dalam tanah mineral. Ion sulfat pada tanah mudah hilang dikarenakan tercuci dan terbawa oleh air, misalnya pada musim penghujan. Sebagian besar sulfur di dalam tanah berasal dari bahan organik yang telah mengalami dekomposisi dari aktivitas vulkanik. Cara terbaik untuk menambahkan cadangan sulfur untuk meningkatkan hasil produksi bawang putih yaitu dengan cara menambahkan bahan organik pada tanaman agar tetap optimal.

Limbah kubis merupakan salah satu tanaman yang dapat dijadikan bokhasi. Bokhasi adalah jenis pupuk organik yang telah difermentasikan dengan EM4, yang dapat memperbaiki sifat fisik, kimia, dan biologi tanah. Kandungan unsur hara yang terdapat pada bokhasi dapat membantu pertumbuhan tanaman [8].

Penggunaan bokhasi kubis (Brassica oleracea var.capitata) telah diteliti oleh Rahmi [9] memperlihatkan bahwa pemberian dosis bokhasi kubis $15 \mathrm{~g}, \quad 17,5 \mathrm{~g}, \quad 20 \mathrm{~g}$, dan 22,5 g tidak berpengaruh nyata terhadap tinggi tanaman, jumlah helai daun, jumlah umbi, berat basah dan berat kering tanaman bawang merah (Allium ascalonicum L). Penelitian Putri [10] memperlihatkan bahwa pemberian beberapa dosis bokhasi Salvinia molesta terhadap pertumbuhan dan produksi tanaman kedelai (Glycine max L)berpengaruh nyata terhadap pertumbuhan dan produksi tanaman kedelai yaitu tinggi tanaman, berat basah dan berat kering tanaman, jumlah polong, jumlah biji dan berat kering biji. Penelitian Didin dkk [11] memperlihatkan bahwa pemberian bokashi rumput naga (Potamogeton sp) terhadap pertumbuhan tanaman jagung manis (Zea mays saccarata Sturt) dalam polybag berpengaruh nyata terhadap pertumbuhan tanaman jagung, dengan komposisi $20 \mathrm{~kg}$ rumput naga, $1 \mathrm{~kg}$ gula pasir, dan $0,5 \mathrm{~kg}$ dedak memberikan hasil terbaik terhadap jumlah daun, tinggi tanaman dan biomassa tanaman. 
Mikroorganisme yang dapat membantu laju proses dekomposisi adalah Effective Microorganisme 4 (EM4). EM4 dapat digunakan untuk pengomposan, karena mampu mempercepat proses dekomposisi sampah organik [12]. Penggunaan EM4 yang diteliti oleh Novita [13] menyatakan bahwa pemberian Efektifitas Mikroorganisme (EM4) terhadap tanaman kacang tanah (Arachis hypodea L) berpengaruh terhadap tinggi tanaman, jumlah polong, dan berat kering biji kacang tanah. Penggunaan EM4 dapat meningkatkan pertumbuhan dan produksi tanaman sehingga sangat baik digunakan dalam mengelola tanaman pertanian.

Berdasarkan permasalahan di atas, penulis telah memanfaatkan limbah kubis (Brassica oleracea var. capitata) sebagai pupuk organik untuk tanaman bawang putih (Allium sativum L) pada tanah podzolik merah kuning sehingga memberikan pengaruh terhadap pertumbuhan bawang putih ( Allium sativum L). Oleh karena itu peneliti telah melakukan penelitian tentang "Bokhasi Added Influence Cabbage (Brassica oleraceavar. capitata) On The Growth OfGarlic(Allium sativumL) On ARed-Yellow Podzolic Soil".

Tujuan penelitian ini untuk mengetahui pengaruh penambahan bokhasi kubis (Brassicaoleracea var. capitata) terhadap pertumbuhan bawang putih (Allium sativum L) pada tanah podzolik merah kuning.

\section{METODE PENELITIAN}

Penelitian eksperimen ini menggunakan Rancangan Acak Lengkap (RAL) dengan 5 perlakuan dan 4 ulangan. Perlakuan adalah pemberian bokhasi kubis (Brassicaoleracea var. capitata) dengan dosis yang berbeda, yaitu $0 \mathrm{~g} /$ polibag (tanpa bokhasi/kontrol), $250 \mathrm{~g}$ bokhasi kubis /polibag, $500 \mathrm{~g}$ bokhasi kubis /polibag, $750 \mathrm{~g}$ bokhasi kubis /polibag dan $1000 \mathrm{~g}$ bokhasi kubis/polibag.

Penelitian dilakukan dari Januari sampai Mei 2015 di Batu Bagiriak, Alahan Panjang dan Laboratorium Fisiologi Tumbuhan Jurusan Biologi, Fakultas Matematika dan Ilmu
Pengetahuan Alam, Universitas Negeri Padang.

Alat-alat yang digunakan antara lain polibag dengan ukuran diameter $30 \mathrm{x} 40 \mathrm{~cm}$, meteran, neraca digital, pengayak tanah dengan ukuran mata saring $5 \mathrm{~mm}$,oven, timbangan, kertas label, alat pengukur $\mathrm{pH}(\mathrm{pH}$ meter), cangkul, neraca Ohauss, gelas ukur, sendok, penggaris, pisau, karung goni, ember, tali rafia dan alat tulis.Bahan yang digunakan dalam pembuatan bokhasi yaitu limbah kubis yang didapatkan dari Pasar Lubuk Buaya Padang, bibit bawang putih, EM4, gula, dedak, air, dan tanah podzolik merah kuning.

Persiapan penelitian dengan menyediakan semua alat dan bahan yang digunakan, bibit bawang putih varietas bakuang didapat didaerah Batu Bagiriak, Alahan Panjang, tanah PMK didapat di Lab Tanah Universitas Andalas dan limbah kubis diambil di Pasar Lubuk Buaya.Pelaksanaan penelitian dengan pemberian bokhasi kubis, penanaman dan pemeliharaan tanaman serta pemanenan tanaman.

Komponen pertumbuhan tanaman yang diamati meliputi tinggi tanaman, jumlah helai daun bawang putih, jumlah siung/umbi bawang putih, berat basah tanaman, berat kering tanaman, jumlah akar dan $\mathrm{pH}$ tanah.

Data hasilpengamatandianalisisdenganuji ANOVA (Analisis of varians) dan bila hasil diperoleh menunjukkan beda nyata maka dilakukan uji lanjut menggunakan DNMRT (Duncan New Multiple Range Test) dengan taraf $5 \%$.

\section{HASIL DAN PEMBAHASAN}

\section{Tinggi Tanaman Bawang Putih}

Hasil pengamatan pengaruh penambahan bokhasi kubis terhadap tinggi tanamanan bawang putih dapat dilihat pada Gambar 1 . Berdasarkan sidik ragam tinggi tanaman bawang putih menunjukkan $\mathrm{F}$ hitung besar dari F tabel., berarti setiap perlakuan memberikan pengaruh berbeda nyata terhadap tinggi tanaman bawang putih. 


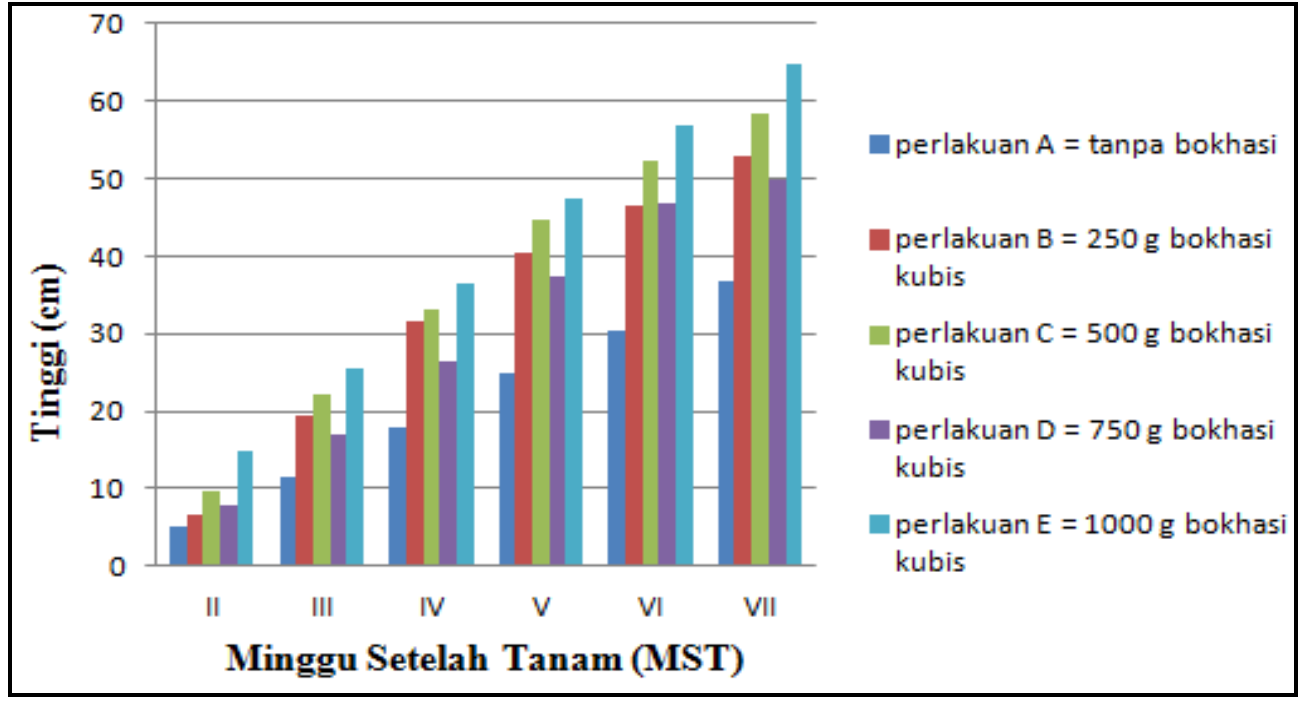

Gambar 1. Rerata pengaruh penambahan bokhasi kubis terhadap tinggi tanaman bawang putih perminggu

Penambahan bokhasi kubis dilakukan sebanyak 2 kali, yaitu dilakukan sebelum bibit ditanam dan pada minggu ke 3 setelah tanam. Perlakuan E (1000 g bokhasi kubis) memiliki rerata tertinggi pada minggu ke 7 setelah tanam, yaitu $64,75 \mathrm{~cm}$ dan rerata terendah adalah perlakuan A (tanpa bokhasi) pada minggu ke 2 setelah tanam yaitu $5,12 \mathrm{~cm}$.

Hasil penambahan pupuk bokhasi kubis dengan dosis 1000 gram dapat memberikan pengaruh pada tinggi tanaman bawang putih jika dibandingkan dengan pemberian pupuk bokhasi kubis 250 gram, 500 garam, dan 750 gram. Semakin banyak penambahan takaran dosis pupuk bokhasi kubis yang diberikan maka semakin tinggi pertumbuhaan tanaman bawang putih.

Salah satu penyebab penambahan bokhasi kubis berpengaruh nyata terhadap tinggi tanaman bawang putih yaitu ketersediaan unsur hara nitrogen $(\mathrm{N})$ yang berperan dalam meningkatkan tinggi tanaman. Pupuk NPK mengandung unsur hara nitrogen $(\mathrm{N})$ yang tinggi, yakni sebesar $15 \%$ dalam bentuk NH3 sehingga dapat mempercepat pertumbuhan tanaman [14]. Menurut Diah [15], unsur nitrogen penting bagi tanaman. Pada umumnya nitrogen sangat diperlukan untuk pembentukan atau pertumbuhan bagian-bagian vegetatif tanaman seperti daun, batang, dan akar.

\section{Jumlah Helai Daun Bawang Putih}

Hasil pengamatan pengaruh penambahan bokhasi kubis terhadap jumlah helai daun tanaman bawang putih dapat dilihat pada Gambar 2. Berdasarkan sidik ragam jumlah helai daun tanaman bawang putih menunjukkan $\mathrm{F}$ hitung besar dari $\mathrm{F}$ table. Berarti setiap perlakuan . memberikan pengaruh berbeda nyata terhadap jumlah helai daun tanaman bawang putih. 


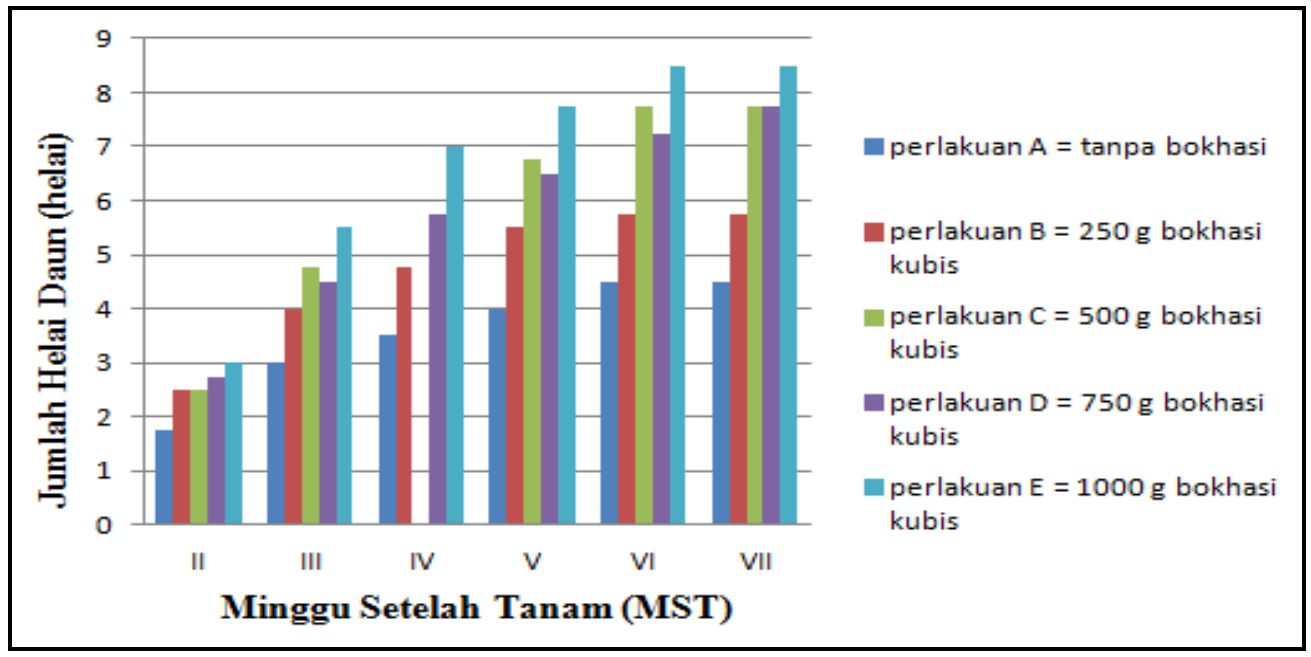

Gambar 2. Rerata pengaruh penambahan bokhasi kubis terhadap jumlah helai daun tanaman bawang putih perminggu.

Perlakuan E (1000 g bokhasi kubis) memiliki rerata tertinggi pada minggu ke 6 setelah tanam dan pada minggu ke 7 setelah tanam, yaitu 8,50 helai dan rerata terendah adalah perlakuan A (tanpa bokhasi) pada minggu ke 2 setelah tanam yaitu 1,75 helai.

Unsur nitrogen mempengaruhi pertumbuhan vegetatif tanaman seperti jumlah helai daun pada tanaman bawang putih. Menurut Napitupulu dan Winarto [14], Nitrogen merupakan komponen struktural dari senyawa organik seperti asam amino, protein, nukleoprotein, enzim dan purin yang sangat dibutuhkan untuk pembesaran dan pembelahaan sel, sehingga pemberian nitrogen optimum akan meningkatkan pertumbuhan vegetatif tanaman. Jadi apabila diberikan peningkatan pada bokhasi, maka daun akan mengalami peningkatan.

Penyebab penambahan bokhasi kubis berpengaruh terhadap jumlah helai daun tanaman bawang putih juga disebabkan oleh keadaan lingkungan yaitu tumbuh pada daerah dataran tinggi yang memiliki kelembaban udara dan suhu udara yang sejuk. Menurut Rahmi [9] kondisi lingkungan yang cukup baik dengan suhu harian yang cukup, ditunjang dengan radiasi sinar matahari yang tinggi maka tanaman akan dapat memanfaatkan radiasi matahari untuk mengoptimalkan hasil fotosintesis dan pertumbuhan vegetatif tanaman

\section{Jumlah Siung/Umbi Tanaman Bawang Putih}

Pengaruh penambahan bokhasi kubis terhadap jumlah siung/umbi tanaman bawang putih dapat dilihat pada tabel 2. Berdasarkan sidik ragam jumlah siung/umbi tanaman bawang putih menunjukkan $\mathrm{F}$ hitung besar dari F tabel (lampiran 3), berarti pada perlakuan memberikan pengaruh berbeda nyata terhadap jumlah siung/umbi tanaman bawang putih.

Dari hasil penelitian pengaruh penambahan bokhasi kubis terhadap jumlah siung/umbi tanaman bawanag putih pada tanah podzolik merah kuning didapatkan bahwa perlakuan E (1000 g bokhasi kubis) memiliki rerata tertinggi yaitu 8,75 siung/umbi dan perlakuan A (tanpa bokhasi) memiliki rerata terendah yaitu 4,00 siung/umbi. Perlakuan A (tanpa bokhasi) berbeda nyata dengan perlakuan B (250 g bokhasi kubis), perlakuan $\mathrm{C}$ (500 $\mathrm{g}$ bokhasi kubis), perlakuan D (750 g bokhasi kubis), dan perlakuan E (1000 g bokhasi kubis). Perlakuan B (250 g bokhasi kubis) berbeda nyata pada perlakuan $\mathrm{E}$ (1000 g bokhasi kubis). 
Tabel 2. Pengaruh penambahan bokhasi kubis terhadap jumlah siung/umbi tanaman bawang putih.

\begin{tabular}{cc}
\hline Perlakuan & Rerata jumlah siung/umbi tanaman bawang putih \\
\hline A & $4,00 \mathrm{a}$ \\
B & $6,00 \mathrm{~b}$ \\
C & $6,50 \mathrm{bc}$ \\
D & $7,00 \mathrm{bc}$ \\
E & $8,75 \mathrm{c}$ \\
\hline
\end{tabular}

Keterangan : Angka yang diikuti oleh huruf yang sama menunjukan berbeda tidak nyata pada taraf $5 \%$ menurut DNMRT

Hasil tanaman bawang putih juga ditentukan oleh perlakuan yang diberikan. Pemberian takaran bokhasi kubis yang berbeda akan memberikan hasil yang berbeda juga. Menurut Vincent dan Yamaguchi [16] pemberian pupuk yang sesuai untuk pertumbuhan tanaman akan mendapatkan hasil yang lebih optimal.

Kelembaban udara dan curah hujan yang cukup pada waktu penanaman mempengaruhi jumlah siung dan diameter umbi yang dihasilkan pada tanaman bawang putih. Menurut Santoso [17] bawang putih dapat tumbuh pada ketinggian antara 700 meter sampai lebih 1100 meter di atas permukaaan laut, karena selama pertumbuhan memerlukaan udara yang sejuk sehingga berpengaruh terhadap produktivitas tanaman bawang putih dalam menghasilkan umbi dan pertumbuhan tanaman.

\section{Berat Basah Tanaman Bawang Putih}

Pengaruh penambahan bokhasi kubis terhadap berat basah tanaman bawang putih dapat dilihat pada tabel 3. Berdasarkan sidik ragam berat basah tanaman bawang putih menunjukkan $\mathrm{F}$ hitung besar dari $\mathrm{F}$ table. Berarti pada perlakuan memberikan pengaruh berbeda nyata terhadap berat basah tanaman bawang putih.

Tabel 3. Pengaruh penambahan bokhasi kubis terhadap berat basah tanaman bawang putih.

\begin{tabular}{cc}
\hline Perlakuan & Rerata berat basah tanaman bawang putih \\
\hline A & $6,35 \mathrm{a}$ \\
B & $11,1 \mathrm{ab}$ \\
C & $21,4 \mathrm{~b}$ \\
D & $25,75 \mathrm{bc}$ \\
E & $34,32 \mathrm{c}$ \\
\hline
\end{tabular}

Keterangan : Angka yang diikuti oleh huruf yang sama menunjukan berbeda tidak nyata pada taraf 5\% menurut DNMRT

Dari hasil penelitian pengaruh penambahan bokhasi kubis terhadap berat basah tanaman bawang putih pada tanah podzolik merah kuning didapatkan bahwa perlakuan E (1000 g bokhasi kubis) memiliki rerata tertinggi yaitu $34,32 \mathrm{~g}$, dan perlakuan A 
(tanpa bokhasi) memiliki rerata terendah yaitu $6,35 \mathrm{~g}$.

Pada tabel 3 terlihat bahwa perlakuan A (tanpa bokhasi) berbeda nyata pada perlakuan C (500 g bokhasi kubis), perlakuan D (750 g bokhasi kubis) dan perlakuan $\mathrm{E}(1000 \mathrm{~g}$ bokhasi kubis). Perlakuan B (250 g bokhasi kubis) dan perlakuan $\mathrm{C}(500 \mathrm{~g}$ bokhasi kubis) berbeda nyata pada perlakuan E (1000 g bokhasi kubis).

Berat basah tanaman berkaitan dengan kemampuan tanaman dalam menyerap air yang ada disekitar perakaran tanaman. Menurut Salisbury dan Ross [18] berat basah tanaman dapat menunjukan aktifitas metabolisme tanaman dan nilai berat basah tanaman dipengaruhi oleh kandungan air jaringan, unsur hara dan hasil metabolisme.

Bobot umbi basah juga dipengaruhi oleh ketersediaan pupuk nitrogen yang diperlukan oleh tanaman. Menurut Napitulu dan Winarto [14] kekurangan nitrogen menyebabkan ukuran umbi kecil dan kandungan air rendah, sedangkan kelebihan nitrogen menyebabkan ukuran umbi besar dan kandungan air rendah.

\section{Berat Kering Tanaman Bawang Putih}

Pengaruh penambahan bokhasi kubis terhadap berat kering tanaman bawang putih dapat dilihat pada tabel 4. Berdasarkan sidik ragam berat kering tanaman bawang putih menunjukkan $\mathrm{F}$ hitung besar dari $\mathrm{F}$ tabel, berarti pada perlakuan memberikan pengaruh berbeda nyata terhadap berat kering tanaman bawang putih.

Dari hasil penelitian pengaruh penambahan bokhasi kubis terhadap berat kering tanaman bawang putih pada tanah podzolik merah kuning didapatkan bahwa perlakuan E (1000 g bokhasi kubis) memiliki rerata tertinggi yaitu $8,15 \mathrm{~g}$ dan perlakuan A (tanpa bokhasi) memiliki rerata terendah pada berat kering tanaman bawang putih yaitu $1,12 \mathrm{~g}$.

Tabel 4. Pengaruh penambahan bokhasi kubis terhadap berat kering tanaman bawang putih.

\begin{tabular}{cc}
\hline Perlakuan & Rerata berat kering tanaman bawang putih \\
\hline A & $1,12 \mathrm{a}$ \\
B & $2,321 \mathrm{~b}$ \\
C & $5,12 \mathrm{~b}$ \\
D & $6,62 \mathrm{bc}$ \\
E & $8,15 \mathrm{bc}$ \\
\hline
\end{tabular}

Keterangan : Angka yang diikuti oleh huruf yang sama menunjukan berbeda tidak nyata pada taraf $5 \%$ menurut DNMRT

Pada tabel 4 terlihat bahwa perlakuan A (tanpa bokhasi) berbeda nyata pada perlakuan C (500 g bokhasi kubis), perlakuan D (750 g bokhasi kubis) dan perlakuan E (1000 g bokhasi kubis).

Bobot umbi kering dipengaruhi oleh pupuk nitrogen yang diperlukan tanaman sebagai sumber nutrisi untuk pertumbuhan tanaman. Pupuk kalium juga memberikan pengaruh nyata terhadap bobot umbi kering per rumpun. Menurut Bassiony dalam Rahmi, [9] pemberian pupuk kalium yang tinggi pada tanaman bawang putih memberikan hasil yang tinggi pada hasil tanaman, dan mendukung perkembangan besar umbi di dalam tanah.

\section{Jumlah Akar Tanaman Bawang Putih}

Pengaruh penambahan bokhasi kubis terhadap jumlah akar tanaman bawang putih dapat dilihat pada tabel 5. Berdasarkan sidik ragam jumlah akar tanaman bawang putih menunjukkan $\mathrm{F}$ hitung besar dari $\mathrm{F}$ Tabel. berarti pada perlakuan memberikan pengaruh berbeda nyata terhadap jumlah akar tanaman bawang putih. 
Tabel 5. Pengaruh penambahan bokhasi kubis terhadap jumlah akar tanaman bawang putih.

\begin{tabular}{cc}
\hline Perlakuan & Rerata jumlah akar tanaman bawang putih \\
\hline A & $23,50 \mathrm{a}$ \\
B & $26,50 \mathrm{ab}$ \\
C & $37,50 \mathrm{~b}$ \\
D & $40,00 \mathrm{bc}$ \\
E & $46,50 \mathrm{bc}$ \\
\hline
\end{tabular}

Dari hasil penelitian pengaruh penambahan bokhasi kubis terhadap jumlah akar tanaman bawang putih pada tanah podzolik merah kuning didapatkan bahwa perlakuan E (1000 g bokhasi kubis) memiliki rerata tertinggi yaitu 46,50 dan perlakuan A (tanpa bokhasi) memiliki rerata terendah pada jumlah akar tanaman bawang putih yaitu 23,50. Pada tabel 5 terlihat bahwa perlakuan A (tanpa bokhasi) berbeda nyata pada perlakuan C (500 $\mathrm{g}$ bokhasi kubis), perlakuan D (750 g bokhasi kubis) dan perlakuan E (1000 g bokhasi kubis).

Pengelolahan tanah yang baik mempengaruhi pada pertumbuhan akar dan menjaga kondisi tanah harus selalu diperhatikan dalam menanam tanaman bawang putih. Menurut Vincent dan Yamaguchi [16] tanaman bawang putih memiliki sistem perakaran yang dangkal dan terbatas karena itu kondisi tanah harus dijaga mendekati kapasitas lapangan selama sebagian besar periode petumbuhannya.

Ketersediaan nitrogen sangat mempengaruhi pertumbuhan tanaman bawang putih. Menurut Diah [15] unsur nitrogen penting bagi tanaman. Pada umumnya nitrogen sangat diperlukan untuk pembentukan atau pertumbuhan bagian-bagian vegetatif tanaman seperti daun, batang, dan akar.

\section{pH Tanah}

Pengaruh penambahan bokhasi kubis terhadap $\mathrm{pH}$ tanah pada tanaman bawang putih dapat dilihat pada tabel $6(\mathrm{pH}$ setelah inkubasi dan $\mathrm{pH}$ setelah panen). Berdasarkan sidik ragam $\mathrm{pH}$ tanah pada tanaman bawang putih menunjukkan $\mathrm{F}$ hitung kecil dari $\mathrm{F}$ tabel , berarti setiap perlakuan tidak memberi pengaruh nyata terhadap $\mathrm{pH}$ tanah pada tanaman bawang putih.

Tabel 6. Pengaruh penambahan bokhasi kubis terhadap $\mathrm{pH}$ tanah (setelah inkubasi dan setelah panen) pada tanaman bawang putih

\begin{tabular}{ccc}
\hline Perlakuan & Rerata $\mathrm{pH}$ tanah (setelah inkubasi) & Rerata $\mathrm{pH}$ tanah (setelah panen) \\
\hline A & 4 & 5 \\
B & 5 & 5 \\
C & 5 & 5 \\
D & 5 & 6 \\
E & 5 & 6 \\
\hline
\end{tabular}

Dari hasil penelitian pengaruh penambahan bokhasi kubis terhadap $\mathrm{pH}$ tanah (setelah inkubasi dan setelah panen) pada tanaman bawang putih didapatkan bahwa perlakuan A (tanpa bokhasi), perlakuan B (250 g bokhasi kubis), perlakuan C (500 g bokhasi kubis), perlakuan D (750 g bokhasi kubis), dan perlakuan E (1000 g bokhasi kubis) tidak memberi pengaruh nyata terhadap $\mathrm{pH}$ tanah pada tanaman bawang putih. 
Media tanam yang digunakan yaitu tanah podzolik merah kuning yang memiliki sifat asam dam minimnya kandungan unsur hara yang terdapat pada tanah. Ini merupakan salah satu kendala dalam menanam tanaman bawang putih. Menurut Sri dkk, [4] tanah PMK bersifat asam dan tingkat kesuburannya rendah.

Kondisi tanah juga mempengaruhi pertumbuhan tanaman bawang putih. Menurut Supriyadi [19] kondisi tanah asam atau alkali akan berpengaruh pada produksi biomassa dan mengurangi aktivitas mikroorganisme dalam tanah. Jadi diperlukan peningkatan produktivitas tanah dengan tindakan pengelolaan kearah ketersedian hara di dalam tanah.

\section{KESIMPULAN}

Berdasarkan hasil penelitian yang telah dilakukan, maka dapat disimpulkan bahwa (1) Penambahan bokhasi kubis (Brassica oleracea var. capitata) berpengaruh nyata terhadap tinggi tanaman bawang putih (Allium sativum $\mathrm{L}$ ) pada tanah podzolik merah kuning; (2) Penambahan bokhasi kubis (Brassica oleracea var. capitata) berpengaruh nyata terhadap jumlah helai daun tanaman bawang putih (Allium sativum L) pada tanah podzolik merah kuning; (3) Penambahan bokhasi kubis (Brassica oleracea var. capitata) berpengaruh nyata terhadap jumlah siung/umbi bawang putih (Allium sativum L) pada tanah podzolik merah kuning; (4) Penambahan bokhasi kubis (Brassica oleracea var. capitata) berpengaruh nyata terhadap berat basah tanaman bawang putih (Allium sativum L) pada tanah podzolik merah kuning; (5) Penambahan bokhasi kubis (Brassica oleracea var. capitata) berpengaruh nyata terhadap berat kering tanaman bawang putih (Allium sativum L) pada tanah podzolik merah kuning; (6) Penambahan bokhasi kubis (Brassica oleracea var. capitata) berpengaruh nyata terhadap jumlah akar tanaman bawang putih (Allium sativum L) pada tanah podzolik merah kuning; (7) Penambahan bokhasi kubis (Brassica oleracea var. capitata) tidak berpengaruh terhadap $\mathrm{pH}$ tanah pada tanaman bawang putih.
Berdasarkan penelitian yang telah dilakukan, disarankan kepada peneliti selanjutnya untuk memperhatikan bibit tanaman bawang putih yang digunakan, memperhatikan keadaan lingkungan pada saat penanaman bawang putih, dan meningkatkan jumlah konsentrasi bokhasi kubis yang digunakan.

\section{DAFTAR KEPUSTAKAAN}

Andi YA. 2013. Efek Ekstrak Bawang Putih (Allium sativum L ) sebagai Larvasida Nyamuk Aedes sp. Laporan Penelitian Universitas Brawijaya. Malang : Universitas Brawijaya.

Dinas Pertanian Propinsi Daerah Istimewa Yogyakarta. 2012. Ttg - Budidaya

Pertanian Bawang Putih Dataran Rendah (Allium sativum L). Jurnal Bidang Produksi Tanaman Pangan dan Hortikultura Seksi Sayuran dan Aneka Tanaman.

Rifqi MC. 2010. Virulensi dan Keanekaragaman Genetika Fusari umoxysporumf sp. cepae Penyebab Busuk Pangkal pada Bawang Putih. Skripsi. Surakarta :Universitas Sebelas Maret.

Sri NK, AJ Marshall, dan BM Beehler. 2012. EkologiPapua. Jakarta :Yayasan Pustaka Obor Indonesia dan Conservation International.

Upik Y, Kasli, M Kasim dan EF Husin. 2009. Kualitas Pupuk Organik Hasil Dekomposisi dan Beberapa Bahan Organik dengan Dekomposernya. Jurnal Akta Agrosia Fakultas Pertanian Universitas Andalas Padang. Padang : Vol.12 No.1:1-7.

Prafitra A, M Hilman, dan FA Rahman. 2012. Pemanfaatan Limbah Sayur Pasar Sebagai Pengganti Pasta Baterai Kering Guna Menghasilkan Listrik Tergantikan. Jurnal Program Kreativitas Mahasiswa. Semarang :UniversitasDiponegoro.

Adiyoga W, M Ameriana, R Suherman, TA Soetiarso, B Jaya, BK Udiarto, R 
Rosliani dan D Mussadad. 2004. Profil Komuditas Kubis. Bandung: Balitsa.

Edison A. 2000. Pengaruh Pemberian Bokhasi dan GA3 Terhadap Pertumbuhan dan Produksi Tanaman Semangka. Skripsi. UIR : Pekanbaru

Rahmi F. 2014. Pengaruh Pemberian Dekomposisi Kubis (Brassica oleracea var. capitata) Terhadap Pertumbuhan Bawang Merah (Allium cepa var. ascalonicum) Pada Tanah Podzolik Merah Kuning.Skripsi. Padang: Universitas Negeri Padang.

Putri K. 2011. Pemberian Beberapa Dosis Bokhasi Salviniam olesta terhadap Pertumbuhan dan Produksi Tanaman Kedelai (Glycine $\max$ L) Pada Tanah Ultisol. Skripsi. Padang : Universitas Andalas.

Didin HM, MS Heraini, IPGN Dwipa dan M Sulthoni. 2011. Pengaruh Bokashi Rumput Naga (Potamogeton sp.) Terhadap Pertumbuhan Tanaman Jagung Manis (Zea mays Saccarata Sturt.) Dalam Polybag. Laporan Penelitian Program Studi Biologi UNLAM. Vol.18, No.2.

Sugihmoro. 1994. Penggunaan Effective Microorganisme 4 (EM4) dan Bahan Organik pada Tanaman Jahe (Zingiber officinale Rose) Jenis Badak. Skripsi. Bogor: Institut Pertanian Bogor.
Novita L. 2012. Pengaruh Penggunaan EM4 Yang Dikulturkan Pada Bokashi Dan Pupuk An-organik Terhadap Produksi Tanaman Kacang Tanah (Arachis hypodaea L) Di Kampung Wanggar Kabupaten Nabire. Skripsi. Nabire : Universitas Satya Wiyata Mandala.

Napitupulu D dan L Winarto. 2010. Pengaruh Pemberian Pupuk $N$ dan $K$ Terhadap Pertumbuhan dan Produksi Bawang Merah,. J. Hort.

Diah S. 2003. Uji Tanah Sebagai Dasar Penyusunan Rekomendasi Pemupukan. Bogor : Balai Penelitian Tanah, Departemen Pertanian.

Vincent dan Yamaguchi. 1998. Sayuran Dunia 2 Prinsip, Produksi dan Gizi Edisi 2. Bandung : Institut Teknologi Bandung Santoso HB. 1998. Bawang Putih. Edisi ke-12. Yogyakarta : Penerbit Kanisius.

Salisbury FB and CW Ross. 1995. Fisiologi Tumbuhan Jilid 3. Bandung : Penerbit ITB.

Supriyadi S. 2008. Kandungan Bahan Organik Sebagai Dasar Pengelolaan Tanah Di Lahan Kering Madura. Jurnal Budidaya Pertanian. Madura : Embryo. 5 (2) : 178. 